\title{
GLOBAL AND UKRAINIAN LABOUR MARKETS IN THE FACE OF DIGITALIZATION CHALLENGES AND THE THREATS OF THE COVID-19 PANDEMIC
}

\author{
Yulia Zaloznova, Oksana Pankova, and Yaroslav Ostafiichuk
}

\begin{abstract}
In the situation of growing global problems and dangers of anthropo-technological, medical-epidemiological, economic, environmental, demographic nature, the demand for identifying transformational changes in global and national labour markets is relevant. The fourth industrial revolution, the threats of the COVID-19 pandemic, the transition to Society 5.0 (Super Smart Society or Society 5.0) are the challenges that change the nature of the world of work, the man of labour, in every country and in humanity as a whole. They create new dangers, are accompanied by unpredictable consequences, but at the same time, they open new opportunities. Therefore, these processes require in-depth research. The purpose of the article is to study transformations on the global and national labour markets caused by the complex impact of digitalization processes and the COVID-19 pandemic. The theoretical and methodological basis of the study combines modern concepts of sustainable development, decent work, social risk and digital economy. Emphasis is placed on the importance to ensure the complementarity of sustainable, labour and digital development. The authors put forward and confirmed the hypothesis that today the transformations in the labour and employment markets are due to the complex influence of modern megatrends, first of all - the COVID-19 pandemic and the digitalization of the economy and society. In the present situation, the COVID-19 pandemic can be a trigger (accelerator) of the digitalization process. The results of the study show that the spread of the COVID-19 pandemic and quarantine restrictions stimulated the growth of demand for digital technologies to meet the communication, professional, consumer and economic needs of the people, contributed to the spread of new non-standard forms of employment using information and communication technologies. The authors present a system of transformational changes in the social and labour sphere in terms of digital and sustainable development; also, they propose key imperatives, priorities of strategic and tactical level to ensure the stabilization and balance of the labour market and employment in Ukraine.
\end{abstract}

Keywords: digital development, sustainable development, social development, labour development, COVID-19 pandemic, transformations, risks, employment

JEL Classification: A13, F29, J21, 033

Yulia Zaloznova, Oksana Pankova, and Yaroslav Ostafiichuk

Virtual Economics, Vol. 3, No. 4, 2020 


\section{Authors:}

\section{Yuliya Zaloznova}

Institute of Industrial Economics of the National Academy of Sciences of Ukraine, 2 Marii Kapnist Street, Kyiv, Ukraine, 03057

E-mail: zaloznova.iep@gmail.com

https://orcid.org/0000-0003-3106-1490

\section{Oksana Pankova}

Institute of Industrial Economics of the National Academy of Sciences of Ukraine, 2 Marii Kapnist Street, Kyiv, Ukraine, 03057

E-mail:pankovaiep@gmail.com

https://orcid.org/0000-0002-2003-8415

\section{Yaroslav Ostafiichuk}

Institute of Industrial Economics of the National Academy of Sciences of Ukraine, 2 Marii Kapnist Street, Kyiv, Ukraine, 03057

E-mail: ost_ya@ukr.net

https://orcid.org/0000-0003-2495-4100

\section{Citation:}

Zaloznova, Y., Pankova, O., \& Ostafiichuk, Y. (2020). Global and Ukrainian Labour Markets in the Face of Digitalization Challenges and the Threats of the COVID-19 Pandemic. Virtual Economics. 3(4), 106130. https://doi.org/10.34021/ve.2020.03.04(6) 


\section{Introduction}

Modern megatrends connected with globalization, digitalization, greening, demographic change, migration and others actualize the problems of transforming and exacerbating imbalances in labour and employment, which seriously affect the state of labour markets both on the global and national levels. The shocking impact of the COVID-19 pandemic on the global and national economies requires in-depth reflection and a consolidated collective response. This situation requires national governments to identify and address imbalances in national labour markets through public policy instruments, taking into account the recommendations by the United Nations, the Organization for Economic Co-operation and Development (OECD), the International Labour Office (ICBM), and the International Labour (ILO) and other relevant international organizations. This is also important for Ukraine in the context of fulfilling the Association Agreement with the EU.

It has become clear that the spread of the COVID-19 pandemic, which has negatively affected economies and labour markets of the vast majority of Europe, North America, East and Central Asia, will further widen global employment imbalances. According to the ILO forecast, depending on the scale of the COVID-19 pandemic impact on the dynamics of world GDP, in 2020 the growth of unemployment in the world may range from 5.3 million ("soft" option) to 24.7 million people ("hard" option); total losses of workers' potential income will potentially range from 860 billion to 3.4 trillion US dollars; the increase in the number of workers impoverished may reach from 8.8 to 35.0 million people, although until recently it has been planned to reduce it by 14.0 million people (Ordonez, 2020).

Due to objective reasons (market imbalances, shocks and cyclical effects etc.), the existence of employment imbalances today is characteristic of almost all national economies. The economic systems of the European Union are not an exception. The imbalance of labour markets hinders the processes of inter-country and interregional convergence (convergence on key parameters of socio-economic development), and instead - causes the opposite processes of divergence. Thus, the IMF report "Prospects for the World Economy" for 2019 argues that an influential factor in strengthening the interregional divergence of labour markets in developed countries are imbalances between professional skills and employers' demands due to production automation processes, and overcoming negative trends requires reforms that increase the level of human capital and flexibility of labour markets (International Monetary Fund. Research Dept., 2019).

There is a low adaptability of the Ukrainian labour market to the latest global changes and threats, the COVID-19 pandemic has led to rising unemployment, job losses and layoffs, underemployment, declining incomes, and social tensions.

The current EU policy agenda is based on the paradigm of the Fourth Industrial Revolution (national programs "Industry 4.0", "Employment 4.0", etc.), digitalization, the knowledge society, and social inclusion (unlike Ukraine). At the same time, the latest EU policy is clearly focused on "human-centric" approaches developed by the Global Commission on the Future 
of Labour, which provide for increased investment in developing human abilities and labour institutions, in decent and stable employment (Kostrytsia \& Burlay, 2020).

The meaning of the Fourth Industrial Revolution is comprehensive automation and robotization of production, cyberphysical systems, biotechnology, 3D printing, alternative energy, artificial intelligence, network economy, augmented reality, circular economy, Internet of Things, blockchain technology, cloud computing, quantum technologies. The use of such technologies has led to digitalization of the real sector of the economy, the change of conventional business models, the spread of employment on platforms. As a result, social and labour relations are being modernized in global and national societies, remote employment is spreading, "digital jobs" are being created, and a new category of labour market actors is emerging: the so-called "smart workers" (Petrova, 2019). The specific features of using labour are flexibility, mobility, rapid updating of knowledge, change of subject-object relations of management, development of creative self-realization in labour processes. According to some estimates, a share of the global information economy, already taking into account digital skills and digital capital, accounts for $22.5 \%$ of the global economy (Knickrehm et al., 2016). This generates serious challenges for all countries in the world without exception and is likely to lead to the degradation of inefficient, non-innovative economies unable to meet these challenges (Sidenko et al., 2017). Therefore, national economies are faced with the need to ensure their own competitiveness and innovation, the ability to respond to the latest challenges of digitalization, to identify opportunities for transition to new technological systems.

Joint burning issues for almost all countries of the world are the extremely low ability to predict the possible consequences of radical technological changes for a man, society, economy, state, and the world as a whole. The effectiveness of digitalization processes in national economies differs significantly. It depends, firstly, on the readiness of certain countries to implement the latest digital technologies (the development level of information and communication technologies and their infrastructure, the parameters of accumulation and use of digital capital, digital skills of the population, etc). Secondly, how ready are the economies for modern production transformations in general: what is the technical and technological level of production, how complex and diverse are its products, how does the national sphere of R\&D contribute to modern industrial development etc. It is obvious that digitalization is not an economic panacea itself, because in a weak innovation sphere, outdated production technologies and worn-out machines and equipment, shortage of STEM staff, it has few prospects and can lead mainly to job losses in services (Vyshnevskyi et al., 2020).

In recent years, numerous studies have been conducted on the problems of the economy digitalization. However, the issues connected with complex impact of digitalization in interaction with other global trends still remain insufficiently disclosed. The presence of a direct effect on the jobs' dynamics (the disappearance of some and the emergence of others) is obvious. But there are also a number of indirect influences, such as changes connected with the rapid spread of information and communication technologies, the impact of the COVID- 
19 pandemic, changes in individual and group behavioural patterns that determine modern patterns of behaviour of economically active population in the labour market. Such processes are integral and contradictory, and their study requires new scientific approaches.

The purpose of the article is to identify the transformations of the global and national labour markets caused by the integral impact of digitalization challenges and threats of the COVID19 pandemic.

Achieving this purpose seems possible if the following tasks are implemented: to identify transformational changes in the labour and employment markets in the context of the economy and society digitalization, the impact of the threats of the COVID-19 pandemic; to substantiate complementarity of sustainable, labour and digital development to provide worthy answers to modern challenges; to identify the key imperatives, strategic and tactical guidelines for stabilizing and balancing of the national labour market in the current conditions.

\section{The Literature Review}

Basic methodological aspects of the concepts of global change, transformations of the world of work and man are presented in the fundamental works by J. Atkinson (Atkinson, 1985), A.B. Laffer (Laffer, 2004), D.F. Gordon (Gordon, 1974), J.M. Keynes (Keynes, 2008), A.C. Pigou (Pigou, 2013), R. Florida (Florida, 2016), C.B. Frey (Frey, 2017), F. Fukuyama (Fukuyama, 2007), M. Castells (Castells, 2000) and others. Issues of functioning, transformations, disparities of the labour market in the context of globalization at the present stage are researched by (Boeri \& Jimeno, 2015; Kapeller et al., 2019; Mau, 2020; Roubini, 2020; Bogachov et al., 2020; Boiko et al., 2019; Czyżewski et al., 2019; Chygryn et al. 2020; Dalevska et al., 2019; Dementyev \& Kwilinski, 2020; Drozdz et al., 2019; 2020; Dzwigol, 2019a; 2019b; 2020a; 2020b; 2020c; Dzwigol \& Wolniak, 2018; Dzwigol \& Dźwigoł-Barosz, 2018; 2020; Dzwigol et al., 2019a; 2019b; 2019c; 2019d; 2020; Furmaniak et al., 2018; 2019a; 2019b; Kharazishvili et al., 2020; Kondratenko et al., 2020; Kuzior et al., 2020; Kwilinski, 2017; 2018a; 2018b; 2018c; 2018d; 2019; Kwilinski et al., 2019a; 2019b; 2019c; 2019d; 2019e; 2019f; 2019g; 2020a; 2020b; 2020c; 2020d; Kwilinski \& Kuzior, 2020; Lakhno et al., 2018; Miskiewicz, 2017a; 2017b; 2018; 2019; 2020a; 2020b; Miśkiewicz \& Wolniak, 2020; Pająk et al., 2016; 2017; Prokopenko \& Miśkiewicz 2020; Saługa et al., 2020; Savchenko et al., 2019; Tkachenko et al., 2019a; 2019b; 2019c; 2019d; 2019e; Yelnikova \& Miskiewicz, 2020) and others.

Problems of transformations in the sphere of labour and employment and the risks that arise under the influence of digitalization are also researched by Ukrainian scientists A. Kolot (Kolot, 2020) , O. Gerasimenko (Gerasimenko, 2019), O. Grishnova (Grishnova et al., 2019), N. Azmuk (Azmuk, 2019), V. Bliznyuk and I. Petrova (Bliznyuk \& Petrova, 2018), V. Kostrytsya and T. Burlay (Kostrytsia \& Burlay, 2020), V. Vyshnevskiy, O. Garkushenko, S. Knyazev (Vyshnevskyi et al., 2020), V. Ljashenko (Ljashenko \& Vyshnevskyj, 2018), O. Novikova (Novikova et al., 2019), Yu. Marshavin (Marshavin, 2018), L. Lisogor (Lisogor et al., 2019), O. Khandii ta L. Shamileva (Khandii \& Shamileva, 2019), O.V. Panjkova and O. Kasperovich (Panjkova \& Kasperovych, 2019), A. Shastun (Shastun, 2020) and others. Their works reveal the factors and 
conditions for emerging socio-economic risks and threats in the socio-labour sphere, and propose preventive measures to minimize their impact. However, the issues that cover the transformations of the sphere of labour and employment in the context of global trends, the disparities that arise in this regard, the problems of complementarity of sustainable, labour and digital development are not given enough attention. All this determined the choice of the topic and the purpose of this article.

\section{Methodology}

The scientific and methodological principles of this study are based on an interdisciplinary approach, due to the complexity of internal relations in the political, economic, socio-cultural systems in the face of increasing challenges and threats at the global and local levels. The theoretical and methodological basis of the study is a combination of modern concepts of sustainable development, decent work, social risk and digital economy.

The authors' approach to the study is based on the hypothesis that today transformations in the social and labour sphere are largely the result of a number of global trends, among which digitalization and technological transition to Industry 4.0 are becoming increasingly important. An important factor in the transformation is the COVID-19 pandemic, which has spread to all continents of the planet, which could be a trigger (accelerator) of the digitalization process.

\section{Results and Discussion}

For now, the functioning of global and national economies need to achieve balance and coherence on the basis of paradigms of digital, sustainable security development. And in the context of the COVID-19 pandemic, this request has special significance and requires appropriate research in ideological (methodological), strategic and tactical fields.

The key principle of counteracting the negative consequences of the COVID-19 pandemic, in particular in the field of labour and employment, is the principle of "building back better", without returning to the level where they were before the COVID-19 crisis. This is a key guideline of the International Labour Organization (ILO) - the ILO Concept Note "Global Summit: COVID-19 and the Labour Sphere" states that whatever the future trajectory of the pandemic is, the labour sphere will be characterized by higher unemployment, inequality, poverty, debt, and possibly, the higher level of popular frustration and intolerance (ILO, 2020a).

In this regard, UN Secretary-General A. Gutterish emphasizes the need to achieve human interests, economic, sustainable and comprehensive recovery using the potential of new technologies to create decent jobs for all and based on creative and positive methods that companies and employees have adapted to this time (Guterres, 2020). And this is just a focus on a complementary system of social, economic, labour, digital development - this is what the authors of this article emphasize. 
According to the National System of Sustainable Development Goals (Ministry of Economic Development and Trade of Ukraine, 2017), the vision of strategic prospects for social and labour transformations is based on the concept of decent work. In the ILO normative documents and declarations, decent work is presented mainly as a political platform designed to "ensure sustainable development, comprehensive and progressive economic growth, mutual benefit and improved integration of policies and goals in macroeconomic, investment and employment, social protection and environmental protection" (ILO, 2020b). According to the ILO's idea of a "just transition" to environmentally sustainable economies, the imperative of a fair and secure transition to a digital economy and digital society should be respected (ILO, 2013). Connection among labour, economic and technological growth, human development, and the environment is synergistic, but not automatic. Jobs provide livelihood and economic security, promote skills and knowledge, facilitate access to education and health services, expand the choice of economic and social behaviour, promote full participation in society, build social cohesion and strengthen ties (ILO, 2015; UNDP, 2015).

Awareness of the nature of new phenomena and processes under the influence of which a new economy and a new social order are formed in connection with digital transformations requires appropriate changes in theoretical and philosophical understanding of the reality as such: societal and technical-technological, economic and social-labour reality etc. This process is widely discussed in scientific circles. Systematic rethinking of the role and consequences of emerging phenomena is very relevant and in demand for both the international and Ukrainian scientific community. In this regard, a valuable conception on this issue is substantiated by Anatolii Kolot - the concept of a new reality, which the author calls "Labour 4.0", as an attempt to combine these aspects into an all-in-one system (Kolot, 2019).

The major points of "Work 4.0" are:

- a new labour paradigm that is immanent to the new economy, the network-digital and technological basis of which is "Industry 4.0" (digital transformation of production processes in enterprises);

- it is a new platform (model) of social and labour development, an institution that ensures the use of labour resources in the conditions generated by the Fourth Industrial Revolution.

We agree with the author that "this phenomenon is not a set of linear, single-vector transformations and mega-changes. In fact, it is a symbiosis of large-scale, multi-vector, ambiguous transformations, some of which open up new possibilities; the second - require the reaction of all subjects of social and labour relations, changes in motivational guidelines, values; the third is frightening without exaggeration". In their essence, they create a new reality, which challenges the traditional system of guaranteeing social protection, social security and national security in general. Guarantees of stable full employment, the system of remuneration, social protection of workers, registration of labour relations, etc. are subject to transformations. These changes are difficult, contradictory and risky processes that simultaneously generate new threats and opportunities (Figure 1). 


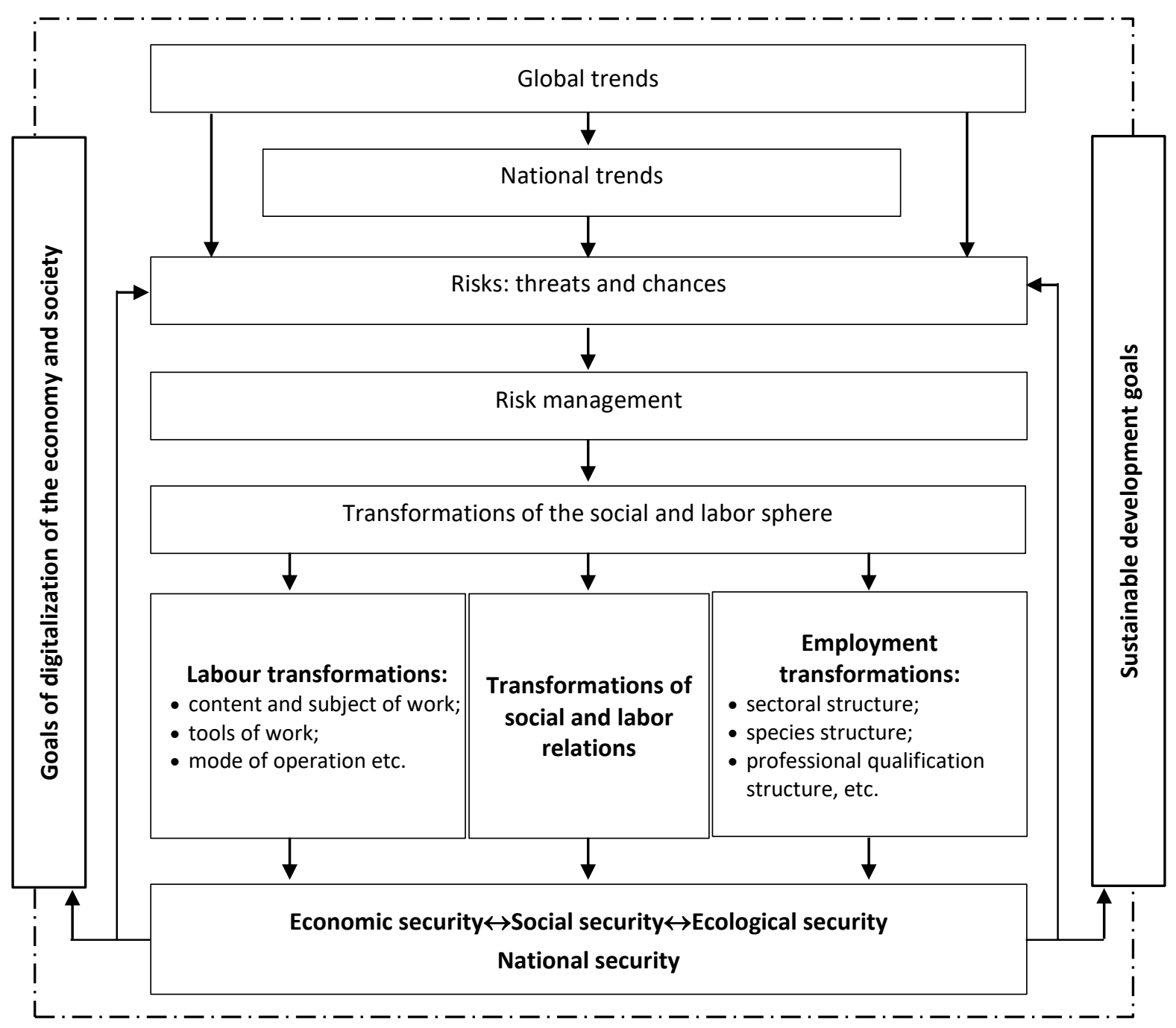

Figure 1. The Scheme of Transforming the Social and Labour Sphere under Conditions of Digital and Sustainable Development Source: developed by the authors.

A specific feature of global trends is a wide range of their impact on all systems of state and society, and the point is that the same trend can affect different situational processes in different countries, localizing a range of problems for the social and labour sphere or creating certain chances for its sustainable development. Potentially, changes caused by global trends can be exacerbated by societal processes at the national level and lead to unpredictable and irreversible changes for the country as a whole.

In the modern world, globalization is an objective process that covers all spheres of economic, political and social life of the country. Due to this, the intensity of connection of national systems to global processes, spatial coverage and the density of interaction among countries and populations are constantly increasing. Researchers show that today the labour market 
and employment in Ukraine, directly or indirectly, are affected by a wide range of global trends, the main among them being:

1) environmental;

2) demographic;

3) medical and epidemiological;

4) socio-behavioural;

5) digital and technological;

6) economic; and

7) political and managerial.

Given the purpose of the article, we will focus on environmental, digital and technological and economic trends, their impact on employment from the standpoint of sustainable balanced and digital development.

Ideas and principles of sustainable development make changes in the philosophy of digitalization processes evaluation. In this perspective, the key task of digitalization is to provide sustainable development using digital technologies for achieving an optimal balance between natural, physical (artificial) and human capital (Figure 2). That is, the greening of the economy should be seen as a process of transition to energy-efficient, resource-saving, innovative and socially inclusive economic model based on the use of digital technologies, technological and social innovations.

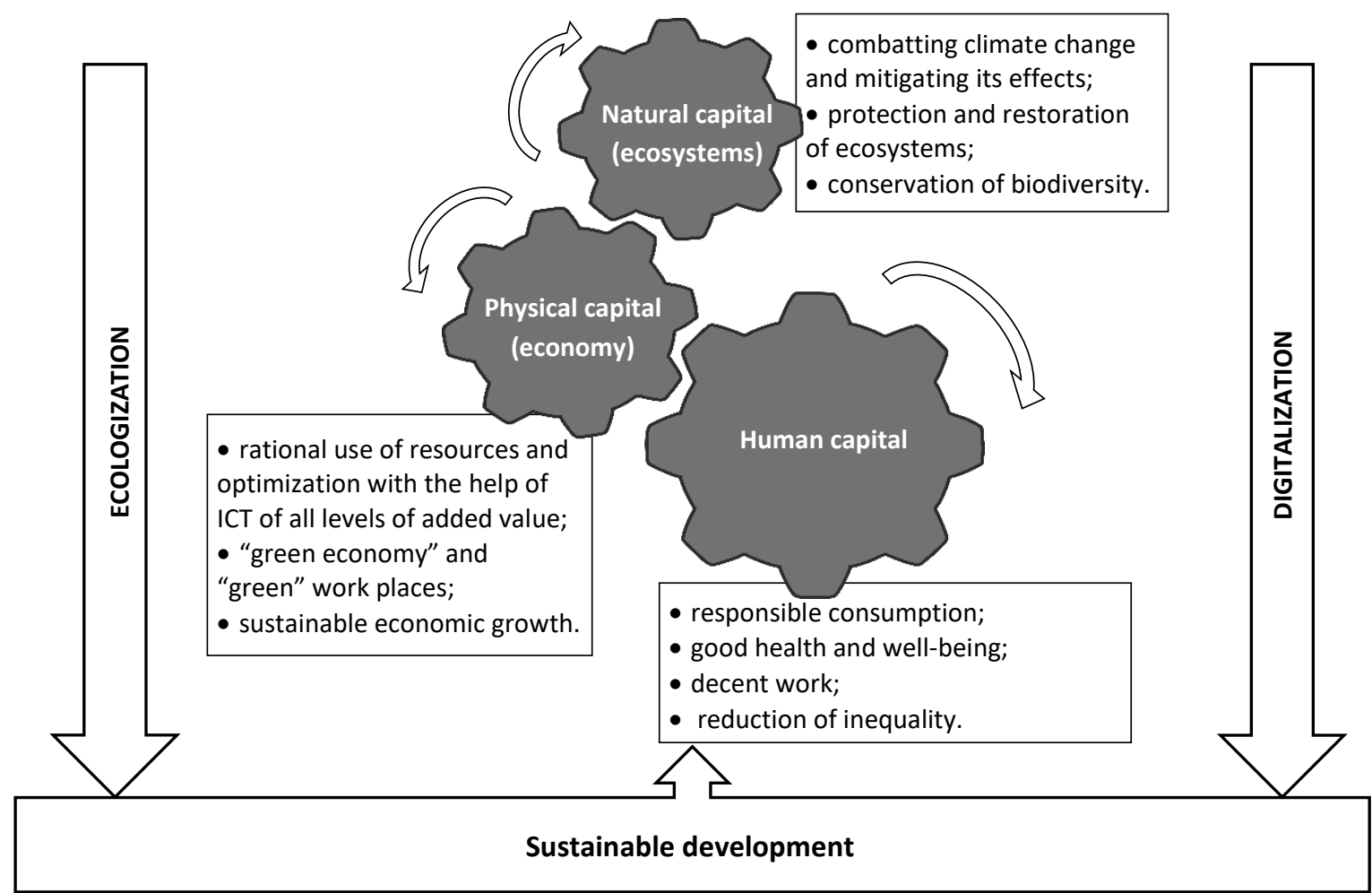

Figure 2. The Relations between Digitalization and Ecologization of the Economy Source: developed by the authors. 
Ecological trends that affect the transformation of the Ukrainian labour and employment sphere, the parameters of human potential (health, life expectancy etc) are climate change, exacerbation of shortages of natural production resources, accumulation of waste, etc., which indirectly causes changes in the structure of demand and labour supply, defining new requirements for production engineering, as well as the attitude of the population to consumption and the nature. The climate change and depletion of the natural resources dictate new conditions for restructuring economies, their reorientation to new technological areas. They also actualize the need to find new resources that can fully or partially replace the existing ones. In particular, the popular concept of a "green" economy sets the task of combating climate change by "greening" work places.

Digitalization can both increase the man-made burden on the environment (it is estimated that information and communication technologies consume about $3.6 \%$ of global electricity and generate $1.4 \%$ of carbon emissions with a tendency to increase (Vaughan, 2018)) and significantly accelerate the pace of "greening", especially through the development of the renewable energy, electric transport, environmental services, which will change the distribution of labour demand by sectors of the economy, quantitative and qualitative characteristics of jobs. According to the Concept of Development of Digital Economy and Society of Ukraine for 2018-2020, the main areas of the ecology digitalization and environmental protection are: Smart usage - "smart" and responsible use and availability of resources (water, etc.), sanitation and hygiene; Smart energy - "smart" energy consumption, increasing the efficiency of energy production and supply; Smart city management - "smart" integrated planning and city management; clear air - ensuring the purity of air, atmosphere; Smart ecosystems - "smart" use of terrestrial and aquatic ecosystems and prevention of biodiversity loss (Cabinet of Ministers of Ukraine, 2018).

Analyses of the digitalization processes made by the Climate Group and the Global Initiative for Sustainable Development emphasize that the world can implement a green economy and move to a low-carbon economy by providing three key functions of information and communication technologies: standardization, monitoring and, consequently, increasing accountability of energy and resources; rethinking based on big data analysis of how we live, learn and work; transformation of existing value chains and integration of infrastructure processes and systems in all sectors of the economy (Perelet, 2018). The largest share of newly created "green" jobs in the world is covered by the production of green goods and services. Thus, according to IRENA (International Renewable Energy Agency, 2016) forecasts, doubling the share of renewable energy sources in the global energy balance will have created more than 24 million jobs by 2030. The total number of jobs in this area in the world continues to grow, in stark contrast to the depressed labour markets in the broad energy sector. "Green" jobs are created not only in new sectors of the economy (renewable energy, etc.), but also in such traditional ones as agriculture, industry, and construction.

So called "green restructuring" is spreading now as a process of reorienting traditional industries in accordance with environmental priorities. In addition, cross-sectoral linkages of green industries also benefit other segments of the economy and create additional jobs 
(indirect jobs) in service activities. "Green restructuring" should become a mandatory direction for implementing reforms in Ukraine. Practically, however, care must be taken to ensure that the process of creating new jobs or "greening" the existing ones based on digital technologies also involves the development of precautionary strategies and action plans aimed at anticipating, identifying, assessing and limiting hazards and risks. The green economy and digitalization do not only create new employment opportunities, they also contain certain threats and the potential for negative consequences for employment.

Current employment structure in Ukraine is such that the dismissal of workers in traditional industries may exceed the labour needs in the newly created "green" jobs, which may contribute to rising unemployment and social tensions. This problem needs additional thorough research. It is necessary to identify what priority public policy measures are needed to address the "fair transition to digital economically sustainable economies" and to minimize the negative consequences while promoting "green" and decent jobs and "greening" traditional industries. According to experts, the transition to a "green" economy for different countries will occur in different scenarios. For an effective transition to a "green" economy in Ukraine, effective policy frameworks must be created to provide the development and implementation of strategies for developing a "green" economy based on an integrative approach, covering all spheres of public life (Razumkov Center, 2019).

Transformations in the field of labour and employment are influenced by trends related to technological innovations, including digital technologies. Network-based use of information and communication technologies (ICT), development of artificial intelligence, intellectualization of data processing and decision-making mechanisms, cloud technologies, new management systems based on digital platforms - all these actively influence the social and economic environment of countries.

Thus, when analysing forecasts for future changes in labour markets, experts from the ILO's Global Commission on the Future of Labour have highlighted those related to technological change - the automation of jobs and operations. The report "Working for a Better Future" states that technological advances (artificial intelligence, automation and robotics) will create new jobs, but those who lose their jobs during this transition may be the least prepared to take advantages of new employment opportunities. The skills that are in demand today will not match the jobs of tomorrow, and the skills acquired may quickly become obsolete (International Labor Office, 2019).

The results of recent studies assessing the impact of automation on workplaces differ significantly depending on methodology, coverage and assumptions made. At the same time, it is undeniable that changing employment patterns will also affect the nature and quality of labour relations and employment, as well as affect the public policy. The relation between productivity and wages is becoming more complex and less direct.

In the modern world of technological and digital transformations, data becomes an asset. Collection, description, storage and processing of big data allow obtaining valuable 
information to be used in business processes, public life, the work of the government. The ability to work with data and analyse it is an opportunity to be the first to receive valuable market "insights", to be more competitive. This opens up previously inaccessible opportunities to concentrate information at such a level that the real labour market can get a cloud representation in the form of an online labour exchange, similar to stock markets. This creates an effective tool for monitoring the dynamics of the labour market, identifying the need for professional skills and relevant trends at different levels (for example, on a territorial or sectoral basis). It involves the development and use of algorithms and artificial intelligence systems to analyse labour market data to assist in providing the effective policy and decision making (Eurostat Statistics Explained, 2020). This knowledge, in turn, gives the direct participants in the labour market interaction the opportunity to make their own predictions and take productive decisions. The greatest benefit from the analysis of Big Data enterprises are obtained by reducing production costs and creating greater opportunities for innovation. Big data analysis also significantly changes sales practice and marketing and significantly affects the field of industry research and development (R\&D). The use of Big Data in the public sector of the economy ensures the effectiveness of implementing the results of forecast modelling, provides new opportunities to save time and public funds in taxation and social security, to reduce corruption etc.

Transformation of the labour market and employment is influenced by global economic trends - established tendencies in economic systems, building economic ties in the global space, sustainable technologies, forms and approaches to doing business. They are manifested in transforming the models of economic development, the emergence of new business models and new models of employment, the liberalization of state regulation of the economy and more (IDSD NASU, 2019). In particular, the specific feature of the new business models is the network nature of interaction with buyers and sellers, the global nature of value chains, clustering and technology of business spaces and processes, contactless business transactions and more. Models of social and non-commercial entrepreneurship aimed at obtaining a social rather than economic effect from organizing activities are becoming widespread. The world economy is significantly affected by business models of the sharing economy, examples of which are cohabitation, car-sharing, office coworking and so on.

The number of people working in new employment models (telework, freelance, outsourcing, outstaffing, staff leasing) is increasing by 3-5\% annually and now in economically developed countries accounts for about a quarter of the officially employed. In countries with developed legal framework in the social and labour sphere, most of the new forms of employment are legitimate and have certain mechanisms of social protection for both the employee and the employer. In less developed countries, non-standard forms of employment are often used as a way to conceal illegal employment or non-permanent temporary employment from time to time due to the lack of appropriate legal framework and culture of social and labour relations. At the same time, websites of crowd-work (micro-tasks) and getting work through electronic applications, which form the economy of digital platforms, can recreate the labour practice of the XIX century and form future generations of "digital day-workers". 
According to an annual Global Human Capital Trends survey by a consulting company Deloitte (Deloitte Insights, 2019), technology helps organizations gain a competitive advantage, but if mismanaged, it also leads to employees' losing their identity in the workplace. Therefore, among companies there is a need to use adequate approaches to personnel management in the modern conditions. By investing in new methods of staff development, leading organizations meet the needs of people in the constant expansion of knowledge and skills to make learning an integral part not only of the work process, but also of life (implementation of the concept of "lifelong learning"). For the career development purposes, continuous training and employee development becomes a prerequisite for job retention.

In Ukraine, the formation of the digital economy goes on slowly. The spread of digital employment is uneven, which leads to separating three segments, where pure digital, mixed and non-digital products are produced. In the future, the maximum share of digital employment will be concentrated in the areas where a pure digital product is produced. According to the available statistics, the number of digital employees in Ukraine in 2018 amounted to 277.8 thousand people, or $3.2 \%$ of the total number of employees. The projected estimate of their number by 2023 will be more than 300 thousand people, or $4.9 \%$ of the total number of employees. The largest share of employees will be in the field of programming (3.7\% of the total number employed). The insignificant share of digital employment in Ukraine is caused by the structure of technological modes in its economy, where III and IV modes predominate with a very insignificant share of $\mathrm{V}$ mode. This structure leads to low demand for digital employment in Ukraine. As a result, the majority of digital workers are outsourced from other countries (Azmuk, 2020).

According to the Ukrainian experts, resources needed to provide an economic basis for productive employment transformations in Ukraine are extremely limited and underdeveloped. There is a significant institutional weakness of the financial sector of the Ukrainian economy. Ukraine is not only characterized by the "embryonic" (compared to developed countries) state of the stock market, but also by the banking system, which survived after 2014 one of the most difficult periods and is determined by a low level of financial stability and efficiency. This is especially evident in the case of investment into a large-scale infrastructure projects that are needed for economic stabilization, to ensure the conditions for sustainable and digital development. The volume of long-term lending to innovative projects by commercial banks remains limited. At the same time, monetary policy directly affects the availability of bank lending negatively (Razumkov Center, 2019).

Thus, the key imperatives for stabilizing and developing the Ukrainian labour market are:

1) to transform labour market institutions and ensure their balanced dynamics under the conditions of external and internal destructive influences, including the negative consequences of the COVID-19 pandemic;

2) to improve the quality and change the structure of employment in accordance with current environmental, technological, economic and other global trends;

3) to transform values in the field of employment, form an innovative labour market;

4) to increase labour productivity, providing a policy of decent wages.

Yulia Zaloznova, Oksana Pankova, and Yaroslav Ostafiichuk

Virtual Economics, Vol. 3, No. 4, 2020 
The imperatives for ensuring the balance of the labour market must be strategic and integrated into the system of strategic development of the social and labour sphere of the Ukraine.

\section{Conclusions}

1. Transformations of the Ukrainian social and labour sphere are (to some extent) a consequence of global influences and cannot be assessed without understanding the relevant global preconditions. This approach allows distinguishing between the scope of national and supranational policies for developing social and labour spheres, determining the tools for influence.

2. Researching the problems of megatrends' influence on the labour markets in the newest conditions needs definition of the system methodological positions: strategic principles and perspective directions of employment transformation in Ukraine, taking into account influence of the main megatrends (opportunities and threats they pose to Ukraine), analysis and estimation of the newest scientific concepts of management according to key dominants, and the national goals of sustainable development for the future, on the one hand, and the existing potential of the state, including basic natural resources, social and labour potential on the other.

3. Modern megatrends that were identified in the study interact with each other, and their impact on national processes is integral and controversial. The close interaction of global trends speaks of the integrity, interdependence and globalization of the processes that occur in the demographic, environmental, economic, social and political spheres of every country. Particularly important in terms of the level of integrated impact are global trends that are emerging in the field of information and technological innovation, which indicates their paramount importance. First of all, this applies to the trend of information and communication revolution and digitalization.

4. Thus, analysis of the modern megatrends' impact on labour markets has shown that digitalization in the context of global environmental trends can both increase the man-made burden on the environment and significantly accelerate the pace of "greening" the economy. Given the current employment structure in Ukraine, the dismissal of workers in traditional industries may exceed the labour needs in the newly created "green" jobs, which will contribute to rising unemployment and social tensions.

Global economic trends are accompanied by the spread of new non-standard employment models, employment growth in the digital economy and on digital platforms. Also, it should be noted that the spread of the COVID-19 pandemic and quarantine restrictions stimulated the demand for digital technologies to meet the communication, consumer and economic needs of the people, especially possibilities for remote employment.

Yulia Zaloznova, Oksana Pankova, and Yaroslav Ostafiichuk

Virtual Economics, Vol. 3, No. 4, 2020 
5. Strategic objectives for adapting the social and labour sphere to epidemiological challenges are the use of entrepreneurial potential to stabilize the situation on the labour market and the potential of new flexible forms of employment based on digital technologies. Assistance should be provided in developing the ecosystem for supporting and accelerating small (including micro) business, in creating a system of competence development, which should help entrepreneurs take their rightful places in the processes of innovative development.

6. "Green restructuring" should become a mandatory reform focus in Ukraine. The process of creating new or "greening" of existing jobs based on digital technologies should involve the development of prevention strategies and action plans aimed at anticipating, identifying, assessing and limiting hazards and risks. The green economy and digitalization do not only create new employment opportunities, they also entail certain threats and potential for negative consequences for employment. Given the current employment structure in Ukraine, the dismissal of workers in traditional industries may exceed the labour needs in the newly created "green" jobs, which will contribute to rising unemployment and social tensions. It is advisable to set public policy priorities to address the "fair transition to digital economically sustainable economies" and to minimize the negative consequences while promoting "green" and decent jobs and landscaping of traditional industries.

7. The use of Big Data in the real sector of the economy will allow the labour market to get a cloud representation in the form of an online labour exchange, similar to stock markets. This opens up new previously unavailable opportunities to concentrate information of such a level that can be the basis for creating effective tools to monitor the labour market dynamics, to identify needs and demand for specific professional skills (for example, on a territorial or sectoral basis). The key point is to develop and use algorithms and artificial intelligence systems to analyse labour market data in order to provide effective policies and decisionmaking.

8. Effective policy, consolidated interaction of main actors of social, socio-economic, technological and innovative development, including investors, an active state position and an effective state policy in the field of digitalization, innovations and investments, sustainable and balanced development should be the basis for overcoming Ukraine's digital, technological lag behind the world's leading countries and the preconditions for transition to energy efficient, resource-efficient, innovative and socially inclusive economy.

For Ukraine, important priorities for international cooperation in the face of the COVID-19 pandemic threats should be:

1. Consistent strengthening of the Ukrainian Government' participation in implementing the International Open Government Partnership Initiative in order to ensure transparency, timeliness and accessibility of information on government activities in accordance with basic international standards of open data on anti-crisis coverage and countering the spread of the COVID-19 pandemic in Ukraine.

2. Ensuring Ukraine's participation in the processes of creating of an international online platform on the activities of the WTO working group on the support and development of 
micro, small and medium enterprises during the COVID-19 pandemic. Participation in the activities of this international online platform includes providing:

- an open access to data that reveals effective mechanisms for ensuring the viability and development of micro, small and medium enterprises in different countries, in particular the results of research and cross-country statistics on them, micro, small and medium enterprises state support programs, information on conferences and seminars, and links to other useful resources;

- information to both representatives of small and medium-sized businesses and civil servants involved in the formation of state policy in this area;

- an opportunity to learn about and disseminate best practices of different countries in implementing the policies on support and development of micro, small and medium enterprises, regulatory impact assessments on such companies and concerning activities in this field carried out by such organizations as the ICC, the OECD, the International Telecommunication Union, the Alliance of World Trade Specialists.

An important strategic guideline for balancing the labour market and employment is the transformation of the labour market into an adaptive self-development ecosystem. This will eliminate imbalances and will help find effective solutions for overcoming the negative effects of the COVID-19 pandemic, other risks and threats.

Formation and implementation of the State policy of Ukraine should be carried out taking into account the positive experience of the European Union and ILO recommendations, but the priority should be given to the national interests of Ukraine and the proper protection of social and labour rights of its citizens.

In Ukraine, the policy of effective government response to challenges and threats should be implemented in the following tactical areas and stages:

in the short term - adaptation and coordination of the State Program of Economic Stimulation adopted by the Cabinet of Ministers of Ukraine to overcome the negative effects caused by restrictive measures to prevent the occurrence and spread of acute respiratory disease COVID-19 for the period 2020-2022 years (including OECD recommendations on the urgent action of employment and social policy needed to support the population and business in response to the COVID-19 pandemic). It is expedient to develop and adopt a Strategy for overcoming the economic crisis in Ukraine and counteracting the consequences of quarantine restrictions in connection with the spread of the COVID-19 pandemic;

in the long term (after stopping the COVID-19 pandemic and abolishing the quarantine regime) the priorities of the state policy should be the adoption of new labour legislation of Ukraine, comprehensive programs to preserve existing and create new jobs, strengthening the institutional role of the State Employment Service, improving the national labour payment system etc.

Effective policy, consolidated interaction of main actors of social, socio-economic, technological and innovative development, including investors, an active state position and an effective state policy in the field of digitalization, innovations and investments, sustainable 
and balanced development should be the basis for overcoming Ukraine's digital, technological lag behind the world's leading countries and the preconditions for transition to energy efficient, resource-efficient, innovative and socially inclusive economy.

Among the areas of further research are the search for optimal models and ways to balance and minimize imbalances in the national labour market and employment during the process of transition to a new technological system (Industry 4.0) and the impact of global and local risks and threats. It is expedient to form a conceptual vision of the adaptive structural model of the labour market ecosystem in Ukraine. Prospects for further research are primarily related to developing scientific approaches to quantifying the risks of digitization; substantiating models and ways of balancing and minimizing imbalances in the labour market and employment in the transition to a new technological way of life and the impact of global and local risks and threats.

\section{References}

Atkinson, J. (1985). Flexibility, Uncertainty and Manpower Management. Retrieved from https://www.employmentstudies.co.uk/system/files/resources/files/89.pdf

Azmuk, N. (2019). Transformation of Employment in the Transition to the Digital Economy: Global Challenges And Adaptation Strategies [monograph]. Kyiv: Znannya.

Azmuk, N. (2020). Strategic Directions of Balancing the Development of the National Labor Market and the Digital Economy. Retrieved from https://iie.org.ua/wpcontent/uploads/2020/08/avtoref_azmuk_maket_4_compressed.pdf

Bliznyuk, V., \& Petrova, I. (2018). Ukrainian Labor Market: Imperatives and Opportunities for Change [Monograph]. Retrieved from http://ief.org.ua/docs/mg/306.pdf

Boeri, T., \& Jimeno, J.F. (2015, November). The Unbearable Divergence of Unemployment in Europe. Working Papers by Banco de España, 1534.

Bogachov, S., Kwilinski, A., Miethlich, B., Bartosova, V., Gurnak, A. (2020). Artificial Intelligence Components and Fuzzy Regulators in Entrepreneurship Development. Entrepreneurship and Sustainability Issues, 8(2), 487-499. http://doi.org/10.9770/jesi.2020.8.2(29)

Boiko, V., Kwilinski, A., Misiuk, M., \& Boiko, L. (2019). Competitive Advantages of Wholesale Markets of Agricultural Products as a Type of Entrepreneurial Activity: The Experience of Ukraine and Poland. Economic Annals-XXI, 175(1-2), 68-72. https://doi.org/10.21003/ea.V175-12

Cabinet of Ministers of Ukraine. (2018). The concept of Development of the Digital Economy and Society of Ukraine for 2018-2020. Retrieved from https://zakon.rada.gov.ua/laws/show/67-2018\%D1\%80\#Text

Castells, M. (2000). The Information Age: Economy, Society and Culture. Moscow: GU VShE.

Yulia Zaloznova, Oksana Pankova, and Yaroslav Ostafiichuk

Virtual Economics, Vol. 3, No. 4, 2020 
Czyżewski, B., Matuszczak, A., \& Miskiewicz, R. (2019). Public Goods Versus the Farm Price-Cost Squeeze: Shaping the Sustainability of the EU's Common Agricultural Policy. Technological and Economic Development of Economy, 25(1), 82-102. https://doi.org/10.3846/tede.2019.7449

Chygryn, O., Bilan, Y., \& Kwilinski, A. (2020). Stakeholders of Green Competitiveness: Innovative Approaches for Creating Communicative System. Marketing and Management of Innovations, 3, 356-368. https://doi.org/10.21272/mmi.2020.3-26

Dalevska, N., Khobta, V., Kwilinski, A., \& Kravchenko, S. (2019). A Model for Estimating Social and Economic Indicators of Sustainable Development. Entrepreneurship and Sustainability Issues, 6(4), 1839-1860. https://doi.org/10.9770/jesi.2019.6.4(21)

Deloitte Insights. (2019). Trends in the Field of Personnel Management. Retrieved from https://www2.deloitte.com/ua/uk/pages/press-room/press-release/2019/human-capital-trends2019.html.

Dementyev, V.V., \& Kwilinski, A. (2020). Institutsionalnaya sostavlyayuschaya izderzhek proizvodstva [Institutional Component of Production Costs]. Journal of Institutional Studies, 12(1), 100-116. https://doi.org/10.17835/2076-6297.2020.12.1.100-116

Drozdz, W., Miskiewicz, R., Pokrzywniak, J., \& Elzanowski, F. (2019). Urban Electromobility in the Context of Industry 4.0. Torun: Wydawnictwo Adam Marszalek.

Drozdz, W., Marszalek-Kawa, J., Miskiewicz, R., \& Szczepanska-Waszczyna, K. (2020). Digital Economy in the Comporary World. Torun: Wydawnictwo Adam Marszalek.

Dzwigol, H. (2019a). The Concept of the System Approach of the Enterprise Restructuring Process. Virtual Economics, 2(4), 46-70. https://doi.org/10.34021/ve.2019.02.04(3)

Dzwigol, H. (2019b). Research Methods and Techniques in New Management Trends: Research Results. Virtual Economics, 2(1), 31-48. https://doi.org/10.34021/ve.2019.02.01(2)

Dzwigol, H. (2020a). Innovation in Marketing Research: Quantitative and Qualitative Analysis. Marketing and Management of Innovations, 1, 128-135. http://doi.org/10.21272/mmi.2020.1-10

Dzwigol, H. (2020b). Methodological and Empirical Platform of Triangulation in Strategic Management. Academy of Strategic Management Journal, 19(4), 1-8.

Dźwigoł, H. (2020c). Interim Management as a New Approach to the Company Management. Review of Business and Economics Studies, 8(1), 20-26. https://doi.org/10.26794/2308-944X-2020-8-1-2026

Dzwigol, H., \& Wolniak, R. (2018). Controlling w procesie zarządzania chemicznym przedsiębiorstwem produkcyjnym [Controlling in the Management Process of a Chemical Industry Production Company]. Przemys/ Chemiczny, 97(7), 1114-1116. https://doi.org/10.15199/62.2018.7.15

Dzwigol, H., \& Dźwigoł-Barosz, M. (2018). Scientific Research Methodology in Management Sciences. Financial and Credit Activity: Problems of Theory and Practice, 2(25), 424-437. https://doi.org/10.18371/fcaptp.v2i25.136508 
Dzwigol, H., \& Dzwigol-Barosz, M. (2020). Sustainable Development of the Company on the Basis of Expert Assessment of the Investment Strategy. Academy of Strategic Management Journal, 19(5), 1-7.

Dzwigol, H., Shcherbak, S., Semikina, M., Vinichenko, O., \& Vasiuta, V. (2019a). Formation of Strategic Change Management System at an Enterprise. Academy of Strategic Management Journal, 18(SI1), 1-8.

Dzwigol, H., Aleinikova, O., Umanska, Y., Shmygol, N., \& Pushak, Y. (2019b). An Entrepreneurship Model for Assessing the Investment Attractiveness of Regions. Journal of Entrepreneurship Education, 22(1S), 1-7.

Dzwigoł, H., Dzwigoł-Barosz, M., Zhyvko, Z., Miskiewicz, R., \& Pushak, H. (2019c). Evaluation of the Energy Security as a Component of National Security of the Country. Journal of Security and Sustainability Issues, 8(3), 307-317. http://doi.org/10.9770/jssi.2019.8.3(2)

Dzwigol, H., Dźwigoł-Barosz, M., \& Kwilinski, A. (2020d). Formation of Global Competitive Enterprise Environment Based on Industry 4.0 Concept. International Journal of Entrepreneurship, 24(1), 1-5.

Dzwigol, H., Dzwigol-Barosz, M., Miskiewicz, R., \& Kwilinski, A. (2020). Manager Competency Assessment Model in the Conditions of Industry 4.0. Entrepreneurship and Sustainability Issues, 7(4), 2630-2644. https://doi.org/10.9770/jesi.2020.7.4(5)

Eurostat Statistics Explained. (2020). Labour Market Flow Statistics in the EU. Retrieved from https://ec.europa.eu/eurostat/statistics-

explained/index.php/Labour_market_flow_statistics_in_the_EU.

Florida, R. (2016). The Rise of the Creative Class. And How it's Transforming Work, Leisure and Everyday Life. Moscow: MIF.

Frey, C. M. (2017). The Future of Employment: How Susceptible Are Jobs to Computerisation? Technological forecasting and social change, 114, 254-280.

Fukuyama, F. (2007). The End of History and the Last Man. Moscow: AST. [in Russian].

Furmaniak, S., Gauden, P.A., Patrykiejew, A., Miśkiewicz, R., \& Kowalczyk, P. (2018). Carbon Nanohorns as Reaction Nanochambers - a Systematic Monte Carlo Study. Scientific Reports, 15407. https://doi.org/10.1038/s41598-018-33725-z

Furmaniak, S., Gauden, P.A., Patrykiejew, A., Miskiewicz, R., \& Kowalczyk, P. (2019a). The Effects of Confinement in Pores Built of Folded Graphene Sheets on the Equilibrium of Nitrogen Monoxide Dimerisation Reaction. Journal of Physics Condensed Matter, 31(13), 135001, 1-12. https://doi.org/10.1088/1361-648X/aaffb3

Furmaniak, S., Gauden, P.A., Patrykiejew, A., Szymański, G., Miśkiewicz, R., \& Kowalczyk, P. (2019b). In Silico Study on the Effects of Carbonyl Groups on Chemical Equilibrium of Reactions with a Polar Product Occurring under Confinement in Pores of Activated Carbons. Chemical Engineering Communications, 1-12. https://doi.org/10.1080/00986445.2019.1700115

Gerasimenko, O. (2019). Socio-Labor Development in the XXI Century: The Nature of Global Change, New Opportunities, Constraints and Challenges. Demography and Social Economy, 97-125.

Yulia Zaloznova, Oksana Pankova, and Yaroslav Ostafiichuk

Virtual Economics, Vol. 3, No. 4, 2020 
Gordon, D. F. (1974). A Neo-Classical Theory of Keynesian Unemployment. Economic Inquiry, 12(4), 431-459. https://doi.org/10.1111/j.1465-7295.1974.tb00415.x

Grishnova, O., Cherkasov, A., \& Brintseva, O. (2019). Transition To A New Economy: Transformation Trends In The Field Of Income And Salary Functions. Problems and Perspectives in Management, $17(2), 18-31$.

Guterres, A. (2020). Secretary-General António Guterres addresses a special event held on the occasion of International Labour Day. Launch of policy brief on COVID-19 and the world of work "The world of work cannot and should not look the same after this crisis". Retrieved from https://www.un.org/en/coronavirus/world-work-cannot-and-should-not-look-same-after-crisis

IDSD NASU. (2019). Global Preconditions Of Asymmetry Of The Ukrainian Labor Market: Report On A Scientific Project. Kiev: IDSD NASU.

ILO. (2013). International Labour Conference, 102 Session. In Sustainable Development, Decent Work And Green Jobs: Fifth Item On The Agenda (p. 23). Geneva: International Labour Office.

ILO. (2015). Guidelines For A Just Transition Towards Environmentally Sustainable Economies And Societies For All. Geneva: ILO.

ILO. (2020a). Global Summit: COVID-19 and the World of Work. Retrieved from https://www.ilo.org/global/topics/coronavirus/events/WCMS_747476/lang--en/index.htm

ILO. (2020b). ILO Implementation Plan - 2030 Agenda for Sustainable Development. Retrieved from https://www.ilo.org/global/topics/sdg-2030/WCMS_510122/lang--en/index.htm

International Labor Office. (2019). Work for a better future. Global Commission on the Future of Work. Retrieved from http://www.ilo.org/wcmsp5/groups/public/---dgreports/--cabinet/documents/publication/wcms_662472.pdf.

International Monetary Fund. Research Dept. (2019). World Economic Outlook: Global Manufacturing Downturn. Rising Trade Barriers. Retrieved from https://www.imf.org/en/Publications/WEO/Issues/2019/10/21/World-Economic-OutlookOctober-2019-Global-Manufacturing-Downturn-Rising-Trade-Barriers-48513

International Renewable Energy Agency. (2016). Renewable Energy and Jobs: Annual Review 2016. Retrieved from https://www.irena.org/publications/2016/May/Renewable-Energy-and-Jobs-Annual-Review-2016

Kapeller, J., Gräbner, C., \& Heimberger, P. (2019, September). Economic Polarisation in Europe: Causes and Policy Options. Retrieved from https://wiiw.ac.at/economicpolarisation-in-europe-causesand-options-for-action-dlp-5022.pdf 10

Keynes, J. (2008). The General Theory of Employment, Interest, and Money. Zurich: ITH.

Khandii, O., \& Shamileva, L. (2019). The Impact of Digital Transformations on the Economy and Labor Sphere: Socio-Economic Risks And Consequences. Ekonomichny`j Visny`k Donbasu, 3(57), 182-188.

Kharazishvili, Y., Kwilinski, A., Grishnova, O., \& Dzwigol, H. (2020). Social Safety of Society for Developing Countries to Meet Sustainable Development Standards: Indicators, Level, Strategic 
Benchmarks (with Calculations Based on the Case Study of Ukraine). Sustainability, 12(21), 8953. https://doi.org/10.3390/su12218953

Knickrehm, M., Berthon, B., \& Daugherty, P. (2016). Digital Disruption: The Growth Multiplier. Optimizing Digital Investments To Realize Higher Productivity And Growth. Retrieved from https://www.accenture.com/_acnmedia/pdf-14/accenture-strategy-digital-disruption-growthmultiplier-brazil.pdf

Kolot, A. (2019). Employment And Income In The Digital Economy: Regulatory Mechanisms, Challenges And Dominants Of Development. In Labor 4.0 As A Model And Platform Of The New (Digital) Economy (pp. 13-28). Kiyv: KNEU.

Kolot, A. (2020). The Sphere of Labor in the Context of the Global Socio-Economic Reality 2020: Challenges For Ukraine. Retrieved from http://library.fes.de/pdf-files/bueros/ukraine/16344.pdf.

Kondratenko, V., Okopnyk, O., Ziganto, L., \& Kwilinski, A. (2020). Innovation Development of Public Administration: Management and Legislation Features. Marketing and Management of Innovations, 1, 87-94. https://doi.org/10.21272/mmi.2020.1-06

Kostrytsia, V.I., \& Burlay, T.V. (2020). Imbalances and Divergence in Employment: EU and Ukraine's Approaches to Overcome IT. Ukrainian Society, 1(72), 83-107.

Kostrytsia, V.I., \& Burlay, T.V. (2020). Imbalances and Divergence in Employment: EU and Ukraine's Approaches to Overcome IT. Ukrainian Society, 1(72), 83-107.

Kuzior, A., Kwilinski, A., \& Tkachenko, V. (2019). Sustainable Development of Organizations Based on the Combinatorial Model of Artificial Intelligence. Entrepreneurship and Sustainability, 7(2), 13531376. http://doi.org/10.9770/jesi.2019.7.2(39)

Kwilinski, A. (2017). Development of Industrial Enterprise in the Conditions of Formation of Information Economics. Thai Science Review, Autumn 2017, 85-90. https://doi.org/10.5281/zenodo.1414236

Kwilinski, A. (2018a). Mechanism of Formation of Industrial Enterprise Development Strategy in the Information Economy. Virtual Economics, 1(1), 7-25. https://doi.org/10.34021/ve.2018.01.01(1)

Kwilinski, A. (2018b). Mechanism of Modernization of Industrial Sphere of Industrial Enterprise in Accordance with Requirements of the Information Economy. Marketing and Management of Innovations, 4, 116-128. http://doi.org/10.21272/mmi.2018.4-11

Kwilinski, A. (2018c). Mechanism for Assessing the Competitiveness of an Industrial Enterprise in the Information Economy. Research Papers in Economics and Finance, 3(1), 7-16. https://doi.org/10.18559/ref.2018.1.1

Kwilinski, A. (2018d). Trends of Development of the Information Economy of Ukraine in the Context of Ensuring the Communicative Component of Industrial Enterprises. Economics and Management, 1(77), 64-70.

Kwilinski, A. (2019). Implementation of Blockchain Technology in Accounting Sphere. Academy of Accounting and Financial Studies Journal, 23(SI2), 1-6. 
Kwilinski, A., Tkachenko, V., \& Kuzior, A. (2019a). Transparent Cognitive Technologies to Ensure Sustainable Society Development. Journal of Security and Sustainability Issues, 9(2), 561-570 http://doi.org/10.9770/jssi.2019.9.2(15)

Kwilinski, A., Drobyazko, S., \& Derevyanko, B. (2019b). Synergetic and Value Effects in Corporate Mergers and Acquisitions of International Companies. In Khalid S. Soliman (Ed.), Proceedings of the 34th International Business Information Management Association Conference (IBIMA) 13-14 November 2019. Vision 2025: Education Excellence and Management of Innovations through Sustainable Economic Competitive Advantage in 2019 (pp. 9467-9471). Madrid, Spain: IBIMA Publishing.

Kwilinski, A., Dalevska, N., Kravchenko, S., Hroznyi, I., Kovalenko, I. (2019c). Formation of the Entrepreneurship Model of E-Business in the Context of the Introduction of Information and Communication Technologies. Journal of Entrepreneurship Education, 22(SI1), 1528-2651-22-S1337: 1-7.

Kwilinski, A., Ruzhytskyi, I., Patlachuk, V., Patlachuk, O., \& Kaminska, B. (2019d). Environmental Taxes as a Condition of Business Responsibility in the Conditions of Sustainable Development. Journal of Legal, Ethical and Regulatory Issues, 22(SI2) 1544-0044-22-SI-2-354: 1-6.

Kwilinski, A., Volynets, R., Berdnik, I., Holovko, M., \& Berzin, P. (2019e). E-Commerce: Concept and Legal Regulation in Modern Economic Conditions. Journal of Legal, Ethical and Regulatory Issues, 22(SI2), 1544-0044-22-SI-2-357: 1-6.

Kwilinski, A., Dzwigol, H., \& Dementyev, V. (2019f). Transnational Corporations as Entities of International Entrepreneurship. International Journal of Entrepreneurship, 23(SI4), 1-6.

Kwilinski, A., Pajak, K., Halachenko, O., Vasylchak, S., Pushak, Ya., \& Kuzior, P. (2019g). Marketing Tools for Improving Enterprise Performance in the Context of Social and Economic Security of the State: Innovative Approaches to Assessment. Marketing and Management of Innovations, 4, 172-181. http://doi.org/10.21272/mmi.2019.4-14

Kwilinski, A., \& Kuzior, A. (2020). Cognitive Technologies in the Management and Formation of Directions of the Priority Development of Industrial Enterprises. Management Systems in Production Engineering, 28(2), 119-123. http://doi.org/10.1515/mspe-2019-0020

Kwilinski, A., Vyshnevskyi, O., \& Dzwigol, H. (2020a). Digitalization of the EU Economies and People at Risk of Poverty or Social Exclusion. Journal of Risk and Financial Management, 13(7), 142. https://doi.org/10.3390/jrfm13070142

Kwilinski, A., Zaloznova, Y., Trushkina, N., \& Rynkevych, N. (2020b). Organizational and Methodological Support for Ukrainian Coal Enterprises Marketing Activity Improvement. E3S Web of Conferences, 168, 00031. https://doi.org/10.1051/e3sconf/202016800031

Kwilinski, A., Dielini, M., Mazuryk, O., Filippov, V., \& Kitseliuk, V. (2020c). System Constructs for the Investment Security of a Country. Journal of Security and Sustainability Issues, 10(1), 345-358. https://doi.org/10.9770/jssi.2020.10.1(25)

Kwilinski, A., Shteingauz, D., Maslov, V. (2020d). Financial and Credit Instruments for Ensuring Effective Functioning of the Residential Real Estate Market. Financial and Credit Activities: Problems of 
Theory and Practice, 3(34), 133-140. Retrieved from https://fkd.ubs.edu.ua/index.php/fkd/article/view/3023

Laffer, A. (2004). The Laffer Curve: Past, Present, And Future. Retrived from https://www.heritage.org/taxes/report/the-laffer-curve-past-present-and-future

Lakhno, V., Malyukov, V., Bochulia, T., Hipters, Z., Kwilinski, A., \& Tomashevska, O. (2018). Model of Managing of the Procedure of Mutual Financial Investing in Information Technologies and Smart City Systems. International Journal of Civil Engineering and Technology, 9(8), 1802-1812.

Lisogor, L., Rudenko, N., \& Chuvardinsky, V. (2019). Competitiveness of the Workforce: Problems of Formation and Implementation in Terms of Innovative Changes In The Market. Economics and Organization of Management, 3, 24-36.

Ljashenko, V.I., \& Vyshnevsjkyj, O.S. (2018). Digital Modernization of Ukraine's Economy as an Opportunity for Breakthrough Development. Kyiv: NAS of Ukraine, Institute of Industrial Economy. [in Ukrainian].

Marshavin, Y. (2018). State Employment Policy in Ukraine: The Need to Reset. Economy and Society, 7, 679-685.

Mau, V. (2020). After The End Of History: How Technological Progress Brings the World Back to the 19th Century. Retrieved from https://www.forbes.ru/finansy-i-investicii/404061-posle-koncaistorii-kak-tehnologicheskiy-progress-vozvrashchaet-mir-v

Ministry of Economic Development and Trade of Ukraine. (2017). Sustainable Development Goals: Ukraine: National Report 2017. Kiev: Ministry of Economic Development and Trade of Ukraine. [in Ukranian].

Miskiewicz, R. (2017a). Knowledge in the Process of Enterprise Acquisition. Progress in Economic Sciences, 4, 415-432. https://doi.org/10.14595/PES/04/029

Miskiewicz, R. (2017b). Knowledge Transfer in Merger and Acquisition Processes in the Metallurgical Industry. Warsaw: PWN.

Miskiewicz, R. (2018). The Importance of Knowledge Transfer on the Energy Market. Polityka Energetyczna, 21(2), 49-62. http://dx.doi.org/10.24425\%2F122774

Miskiewicz, R. (2019). Challenges Facing Management Practice in the Light of Industry 4.0: The Example of Poland. Virtual Economics, 2(2), 37-47. https://doi.org/10.34021/ve.2019.02.02(2)

Miskiewicz, R. (2020). Internet of Things in Marketing: Bibliometric Analysis. Marketing and Management of Innovations, 3, 371-381. http://doi.org/10.21272/mmi.2020.3-27

Miskiewicz, R. (2020). Efficiency of Electricity Production Technology from Post-Process Gas Heat: Ecological, Economic and Social Benefits. Energies, 13(22), 6106. https://doi.org/10.3390/en13226106

Miśkiewicz, R, \& Wolniak, R. (2020). Practical Application of the Industry 4.0 Concept in a Steel Company. Sustainability, 12(14), 5776. https://doi.org/10.3390/su12145776

Novikova, O., Khandii, O., \& Ostafiichuk, Ya. (2019). Mechanism of Strengthening Social and Labor Potential of Sustainable Development. Problems of Sustainable Development, 14(1), 63-72. 
Ordonez, J. (2020). Almost 25 Million Jobs Could be Lost Worldwide as a Result of COVID-19, Says ILO. Retrieved from https://www.ilo.org/moscow/news/WCMS_738742/lang--en/index.htm

Pająk, K., Kamińska, B., \& Kvilinskyi, O. (2016). Modern Trends of Financial Sector Development under the Virtual Regionalization Conditions. Financial and Credit Activity: Problems of Theory and Practice, 2(21), 204-217. https://doi.org/10.18371/fcaptp.v2i21.91052

Pająk, K., Kvilinskyi, O., Fasiecka, O., \& Miskiewicz, R. (2017). Energy Security in Regional Policy in Wielkopolska Region of Poland. Economics and Environment, 2(61), 122-138.

Panjkova, O.V., \& Kasperovych, O.Yu. (2019). Disproportions of Socio-Economic Development in the Conditions of Digitalization: Problems And Risks For The Labor Market Of Ukraine. Rynok Praci ta Zajnjatistj Naselennja, 3(59), 35-43.

Perelet, R. (2018). Environmental Aspects of the Digital Economy. Mir Novoy Ekonomiky, 12(4), 39-45.

Petrova, I. (2019). Proceedings of the Scientific and Practical Conference Employment and Income in the Digital Economy: Regulatory Mechanisms, Challenges and Dominants of Development. In Transformation of Employment in the Digital Economy (pp. 225-227). Kiyv: KNEU.

Prokopenko, O., \& Miśkiewicz, R. (2020). Perception of "Green Shipping" in the Contemporary Conditions. Entrepreneurship and Sustainability Issues, 8(2), 269-284. https://doi.org/10.9770/jesi.2020.8.2(16)

Pigou, A. (2013). Theory of Unemployment. London: Routledge.

Razumkov Center. (2019). "Green" Investments in Sustainable Development: World Experience and Ukrainian Context. Analytical Report. Kyiv: Razumkov Center.

Roubini, N. (2020). A Very Great Depression. 10 Sinister Trends for the World. Retrieved from https://nv.ua/opinion/krizis-2020-o-glavnyh-ugrozah-dlya-mira-nuriel-rubini-poslednie-novosti50086161.html

Saługa, P.W., Szczepańska-Woszczyna, K., Miśkiewicz, R., \& Chłąd, M. (2020). Cost of Equity of CoalFired Power Generation Projects in Poland: Its Importance for the Management of DecisionMaking Process. Energies, 13(18), 4833.https://doi.org/10.3390/en13184833

Savchenko, T., Basiurkina, N., Rodina, O., \& Kwilinski, A. (2019). Improvement of the Assessment Methods of Product Competitiveness of the Specialized Poultry Enterprises. Management Theory and Studies for Rural Business and Infrastructure Development, 41(1), 43-61. https://doi.org/10.15544/mts.2019.05

Shastun, A. (2020). International Scientific Conference Economy Digitalization: Processes, Strategies, Technologies: Conference Proceedings. In Digital And Social Development: Challenges To Public Administration (pp. 108-111). Kielce, Poland: Baltija Publishing.

Sidenko, V. (2017). Structural Transformations in the World Economy: Challenges for Ukraine. Analytical Report. Kyiv: Zapovit.

Tkachenko, V., Kwilinski, A., Korystin, O., Svyrydiuk, N., \& Tkachenko, I. (2019a). Assessment of Information Technologies Influence on Financial Security of Economy. Journal of Security and Sustainability, 8(3), 375-385. http://doi.org/10.9770/jssi.2019.8.3(7) 
Tkachenko, V., Kwilinski, A., Klymchuk, M., \& Tkachenko, I. (2019b). The Economic-Mathematical Development of Buildings Construction Model Optimization on the Basis of Digital Economy. Management Systems in Production Engineering, 27(2), 119-123. http://doi.org/10.1515/mspe2019-0020

Tkachenko, V., Kwilinski, A., Tkachenko, I., \& Puzyrova, P. (2019c). Theoretical and Methodical Approaches to the Definition of Marketing Risks Management Concept at Industrial Enterprises. Marketing and Management of Innovations, 2, 228-238. http://doi.org/10.21272/mmi.2019.2-20

Tkachenko, V., Kwilinski, A., Kaminska, B., Tkachenko, I., \& Puzyrova, P. (2019d). Development and Effectiveness of Financial Potential Management of Enterprises in Modern Conditions. Financial and Credit Activity: Problems of Theory and Practice, 3(30), 85-94. https://doi.org/10.18371/fcaptp.v3i30.179513

Tkachenko, V., Kuzior, A., \& Kwilinski, A. (2019e). Introduction of Artificial Intelligence Tools into the Training Methods of Entrepreneurship Activities. Journal of Entrepreneurship Education, 22(6), 110.

UNDP. (2015). Human Development Report 2015 Work for Human Development. New York: UNDP.

Vaughan, A. (2018). 'Much Work Needed' to Make Digital Economy Environmentally Sustainable. The Guardian. Retrieved from https://www.theguardian.com/environment/2018/feb/20/much-workneeded-to-make-digital-economy-environmentally-sustainable.

Vyshnevskyi, V.P., Harkushenko, O.M., \& Kniaziev, S.I. (2020). Digitalization of Ukrainian Economy: Transformational Potential. Kyiv: Institute of the Economy of Industry of the NAS of Ukraine.

Yelnikova, Y., \& Miskiewicz, R. (2020). Implementation Mechanism of Impact Investing in the PostConflict Regions. Financial Markets. Institutions and Risks, 4(3), 53-65. https://doi.org/10.21272/fmir.4(3).53-62.2020 